\title{
A Typical Mediterranean Fishery and an Iconic Species: focus on the common Spiny Lobster (Palinurus elephas, Fabricius, 1787) in Corsica
}

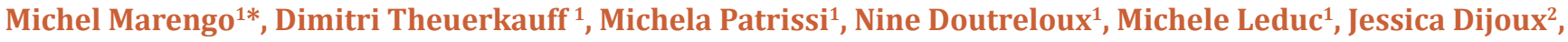
Coralie Duchaud ${ }^{2}$, Cédric R. Picot ${ }^{3}$, Rémy Agniel ${ }^{3}$, Jean-Michel Culioli ${ }^{4}$, Marie-Catherine Santoni ${ }^{4}$, Sylvie Gobert $^{1,5}$, Patrick Berrebi ${ }^{6}$, Yann Quilichini ${ }^{7}$, Sonia Ternengo ${ }^{7,8}$, Eric Dominique Henri Durieux ${ }^{7,8}$ and Pierre Lejeune $^{1}$
\end{abstract}

${ }^{1}$ STAtion de REcherche Sous-marines et Océanographiques (STARESO), France

${ }^{2}$ Comité Régional des Pêches Maritimes et des Élevages Marins de Corse (CRPMEM), France

${ }^{3}$ ERRMECe, Equipe de Recherche sur les Relations Matrice Extracellulaire-Cellules (EA1391), France

${ }^{4}$ Office de l'Environnement de la Corse (OEC/UAC), France

${ }^{5}$ Université de Liège (ULiège), Centre MARE, Laboratoire d'Océanologie, Sart-Tilman, Belgium

${ }^{6}$ GENOME - Recherche \& Diagnostic, France

${ }^{7}$ Université de Corse (Univ-Corse), CNRS, UMR SPE 6134, France

${ }^{8}$ Université de Corse (Univ-Corse), UMS 3514 CNRS-UCPP Stella Mare, France

Submission: February 10, 2020; Published: June 29, 2020

Corresponding author: Michel Marengo, STARESO Marine station, STARESO, Punta Revellata, BP33, 20260, Calvi, France

Abstract

The common spiny lobster (Palinurus elephas, Fabricius, 1787) is an iconic species of the Mediterranean Sea. Despite the existence of data on the artisanal fishery of P. elephas in the Mediterranean Sea and particularly in Corsica, knowledge on the biology and life history traits of this iconic species is still lacking. This paper identifies the main gaps in current knowledge and suggests future directions of research to answer these fundamental questions, which are currently unanswered.

Kewords: Small-scale fisheries; Mediterranean Sea; common spiny lobster; Genetic; Age; Growth; Movement; Connectivity

\section{Introduction}

The common spiny lobster (Palinurus elephas, Fabricius, 1787) is an iconic species of the Mediterranean Sea. This species has a wide geographic distribution spreading along the Northeast Atlantic coasts (from the south of Norway to Mauritania including the Canary Islands and the Azores) and along the Mediterranean coasts except in the extreme eastern and south-eastern basins [1]. The common spiny lobster mainly colonizes rocky bottoms associated with various coralligenous assemblages between 0 and $200 \mathrm{~m}$ deep [2]. The movements of $P$. elephas have been reported rarely in the literature, but it is considered to be a sedentary species with a low level of mobility. The only tagging experiments, in the Atlantic and the Mediterranean (recapture rate between 5-10\%), show limited movements, generally less than $5 \mathrm{~km}$, even if some recaptures have been recorded more than fifty kilometers away $[3,4]$. However, larval stage seems to be the main way of dispersal. The maximum size reported for this species is $50 \mathrm{~cm}$ (total length). The lifespan of this crustacean is important, its longevity can reach a maximum age of 30 years (maximum estimated age) [5]. The age of reproduction is late for lobsters as it needs 5-6 years to become adult and sexually mature, which corresponds to an average size (Cephalothoracic Length, CL) of $86 \mathrm{~mm}$ for females and $76 \mathrm{~mm}$ for males in the Mediterranean Sea [5]. As the growth of crustaceans depends on its environment (quantity of food, pollution), estimating its age is a major challenge [6]. In fish, direct anatomical aging methods have been developed on 
specific structures, e.g. otoliths or scales, that can record annual growth rings [7]. However, in crustaceans, it has been assumed that growth bands do not exist due to the loss of hard structures with the moult [8]. This moult with the loss of the hard structure has known to "trash" molecular damage. This complicates the estimation of the age of crustaceans by this method. Thus, new approaches are being developed using age pigment markers (e.g, lipofuscin) to more precisely determine the age of crustaceans [9].

P. elephas has a particularly long larval stage in the Western Mediterranean basin with eggs hatching in December and last larval stage recruitment (Puerulus) on coastal hard bottoms occuring in May-June. While larvae distribution during this long pelagic phase remains unknown, larval morphology (Phyllosoma) tends to show that larvae are adapted to move offshore in the whole Western Mediterranean basin. Nonetheless, periodic events (several years periodicity) of massive recruitment have been reported [10] and it could take place simultaneously throughout the basin (Corsica, Baleares, Spain Coast). This suggests that the recruitment success of Mediterranean $P$. elephas is tightly linked to large-scale oceanographic processes and therefore that the resource might be under the pressure of climate change [11].

Beyond individual characteristics, data at a population level are still scarce. Genetics have long been recognized for its usefulness in identifying the populations structure and determining connectivity [12]. The identification of the structure of exploited stocks is fundamental for sustainable management of fisheries by determining appropriate spatial units [13]. Several genetic studies, based on microsatellite analyses and mitochondrial DNA sequencing, have revealed that, instead of forming a panmictic unit, the populations of P. elephas formed two distinct groups corresponding to the Atlantic and the Western Mediterranean basin [14,15].

The common spiny lobster focuses on certain environmental, societal and economic interests in the Mediterranean Sea. P. elephas is a species which has a high commercial value and represents an important economic interest for artisanal fishing. The selling price of spiny lobster fluctuates between 50 and $100 €$ per kilo depending on the period of year and the type of sale (fishmongers, restaurants or individuals). Despite of this, according to the International Union for Conservation of Nature (IUCN), overexploitation by professional fishing is a major threat to the spiny lobster which has been classified as a "Vulnerable " species in the Red List of Threatened Species. Indeed, the spiny lobster is highly vulnerable to fishing because of its life history features including its long life and low growth rate and it was recognized that fishing pressure can induce changes in evolutionary traits such as growth rate and age at maturity [1].

Regarding fishing at the global level, common spiny lobster landings have been in decline since the 1960s despite strong interannual variability. Official capture production statistics from the FAO for P. elephas in Europe showed a dramatic decline from
1100 tons in 1969 to 434 tons in 2017. For more than 50 years, commercial fisheries landings have experienced a $60 \%$ drop. While P. elephas were traditionally fished using traps, a selective gear, these latter devices were largely replaced in the 60 s and 70 s by trammel nets. This change suddenly increased the fishing pressure, but also the characteristics of the exploited populations.

P. elephas is an important marine resource in the Mediterranean Sea, and particularly in Corsica. However, Corsica was not exempted from the overall downward trend of catches as production decreased from an average of 300 tons per year in the 1970s to an average of around 80 tons per year in the 2000s [16]. Yet, Corsica is considered as an area where fishing pressure is low compared to the rest of the Mediterranean [17]. The fishing activity in Corsica is artisanal and relies on a multi-specific and multigear activity fleet of 166 units spread over 4 Prud'homies (Ajaccio, Bonifacio, Bastia-Cap Corse and Balagne) in 2019.

The opening period for lobster fishing in Corsica begins March $1^{\text {st }}$ and ends on September the $30^{\text {th }}$, in order to avoid the mating and spawning period (in September). Corsican regulations also require that the total net length per vessel do not exceed $5000 \mathrm{~m}$. The 2006 European Council regulation (EC, No 1967/2006) on professional fishing prohibits to market grained females and sets the minimum catch size for P.elephas at $90 \mathrm{~mm}$ CL for the European Mediterranean Sea. The fishing effort is praticed mainly on the West coast and on a zone between 0 and 3 nautical miles. The most used fishing gear currently for spiny lobster in Corsica is the trammel net (nylon or braided), generally of mesh size between 4 and 6 . The duration of fishing operations is variable, usually a minimum of two days. The spatial study of fishing zones shows that the spiny lobster is distributed in a heterogeneous way in Corsica [18]. It is generally observed that the lowest Catch Per Unit of Effort (CPUE) values are between 0 and $50 \mathrm{~m}$ deep while the maximum values are mainly between 50 and $200 \mathrm{~m}$ deep [19]. Sampled individuals showed a wide spectrum of capture in the artisanal fishery, ranging from juveniles to adults, from $20 \mathrm{~mm}$ to $157 \mathrm{~mm}$ in CL [19].

Despite the existence of data on the artisanal fishery of $P$. elephas in the Mediterranean Sea and particularly in Corsica, knowledge on the biology and life history traits of this iconic species is still lacking.

It is in this context that five partners (STARESO, CRPMEM, OEC/UAC, CY, Univ-Corse-CNRS) bringing together scientists, managers and fishermen, initiated the ALIGOSTA collaborative research program. The ALIGOSTA project (2020-2023) aims to improve the state of knowledge on the biology and population structure of P. elephas in Corsica. More precisely, the project objectives are to:

I. Explore the opportunities and the feasibility of new direct age determination techniques, by the detection and characterization of senescence markers (e.g: lipofuscin, 
$\beta$-galactosidase, oxidative stress). Investigate the relation between the rate of cell aging and the appearance of these markers according to the stages of spiny lobster development. Compare these age estimates with "classic" growth models (e.g. Von Bertalanffy, Bhattacharya, Powell-Wetherall).

II. Estimate the size-fertility relationship, the fertile biomass and the reproductive potential of $P$. elephas around Corsica, study primary/secondary sexual characteristics, test their reliability to determine the physiological, morphological and functional maturity of the species. Study the potential modifications of evolutionary/morphological traits both at macroscopic and microscopic level and the selection processes induced by fishing pressure.

III. Improve the understanding of connectivity and population dynamics using genetic markers (e.g. microsatellites). Estimate the extent of gene flow and connectivity among populations of P. elephas in Corsica. Evaluate the effect of different oceanographic barriers (currents, water masses) and protection measures (e.g. Marine Protected Areas) on the population structure. Examine whether the current genetic variability of $P$. elephas is affected by the current overfishing and/or by historical factors.

IV. Estimate population parameters such as abundance, survival, recruitment and movement using Capture-MarkRecapture (CMR) methods. Study the movement skills (e.g. home range) and identify the spatial scale of these movements using techniques such as individual external marking (e.g. spaghetti tags). These methods could help to understand individual movements and potential exchanges between populations and complement the results regarding to the population structure identified by genetic markers.

\section{Conclusion}

The goal of this project is to provide essential elements in the life history traits of this species. These data could be used as a basis for assessing the state of the stock and modeling population dynamics in order to contribute to sustainable fisheries management in Corsica. The exploitation of fish stocks with Maximum Sustainable Yield (MSY) is a predominant objective of the Common Fisheries Policy (CFP). Determining the MSY and assessing the state of the stocks in relation to this target is based on demographic models which require knowledge of many parameters of the life cycle of fish species. These parameters are used in the analysis of yield per recruit, the estimation of fertile biomass, the stock-recruitment relationship and the age distribution of catches. This project will provide local stakeholders and decision-makers with a better understanding of the role of this species in the ecosystem and predict the possible ecological consequences of various management measures and / or the impact of climate change.

\section{Acknowledgment}

This research was funded by the "PO FEAMP 2014-20, Mesure 28" and the "France Filière Pêche", as part of the ALIGOSTA project research. This study was also funded by the "Agence de l'eau Rhône Méditerranée Corse" and the "Collectivité de Corse", in the framework of the STARECAPMED program.

\section{References}

1. Goñi R, Latrouite D (2005) Review of the biology, ecology and fisheries of Palinurus spp. species of European waters: Palinurus elephas (Fabricius, 1787) and Palinurus mauritanicus (Gruvel, 1911). Cahiers de Biologie Marine 46: 127-142.

2. Campillo A, Amadei J (1978) Premières données biologiques sur la langouste de Corse, Palinurus elephas, Fabricius. Revue des Travaux de l'Institut des Pêches Maritimes. 42: 347-373.

3. Cau A, Bellodi A, Cannas R, Fois M, Guidetti P, et al. (2019) European spiny lobster recovery from overfishing enhanced through active restocking in Fully Protected Areas. Sci Rep 9: 13025.

4. Follesa MC, Cuccu D, Cannas R, Sabatini A, Deiana, AM, et al. (2009) Movement patterns of the spiny lobster Palinurus elephas (Fabricius, 1787) from a central western Mediterranean protected area. Sci Mar 73: 499-506.

5. Marin J (1987) Exploitation, biologie et dynamique du stock de langouste rouge de Corse, Palinurus elephas Fabricius. Université d'Aix-Marseille II.

6. Wahle RA, Fogarty MJ (2006) Growth and development: understanding and modelling growth variability in lobsters. Lobsters: biology, management, aquaculture and fisheries. Wiley Online Library, 10: 1.

7. Campana SE (2001) Accuracy, precision and quality control in age determination, including a review of the use and abuse of age validation methods. Journal of Fish Biology. 59(2): 197-242.

8. Vogt G (2012) Ageing and longevity in the Decapoda (Crustacea): a review. Zoologischer Anzeiger-A Journal of Comparative Zoology. Elsevier 251: 1-25.

9. Maxwell KE, Matthews TR, Bertelsen RD, Derby CD (2009) Using age to evaluate reproduction in Caribbean spiny lobster, Panulirus argus, in the Florida Keys and Dry Tortugas, United States. New Zealand Journal of Marine and Freshwater Research 43: 139-149.

10. Diaz D, Leduc M, Patrissi M, Abadie A, Muñoz A, et al. (2017) Understanding settlement dynamics of the european spiny lobster $\mathrm{Pa}-$ linurus elephas) in the mid-western mediterranean. Portland, Maine.

11. Gobert S, Fullgrabe L, Lejeune P, Marengo M (2020) Climate Change and Fisheries: The Case Study of Corsica, an Ideal Reference Station in the Mediterranean Sea. Aquaculture and Fisheries Studies. $1^{\text {st }}$ (edn.), pp. 1-2.

12. Ward R (2000) Genetics in fisheries management. Hydrobiologia 420: 191-201.

13. Mariani S, Hutchinson WF, Hatfield E, Ruzzante DE, Simmonds EJ, et al. (2005) North Sea herring population structure revealed by microsatellite analysis.

14. Babbucci M, Buccoli S, Cau A, Cannas R, Goñi R, et al. (2010) Population structure, demographic history, and selective processes: Contrasting evidences from mitochondrial and nuclear markers in the European spiny lobster Palinurus elephas (Fabricius, 1787). Molecular Phylogenetics and Evolution. 56(3): 1040-1050. 
15. Palero F, Abelló P, Macpherson E, Beaumont M, Pascual M (2011) Effect of oceanographic barriers and overfishing on the population genetic structure of the European spiny lobster (Palinurus elephas): Population genetics of palinurus. Biological Journal of the Linnean Society 104(2): 407-418.

16. Le Manach F, Dura D, Pere A, Riutort JJ, Lejeune P, et al. (2011) Preliminary estimate of total marine fisheries catches in Corsica. Fisheries Centre Research Reports 19: 3.

17. Relini G, Bertrand J, Zamboni A (1999) Synthesis of the knowledge on bottom fishery resources in central Mediterranean (Italy and Corsica). Biologia Marina Mediterranea. 6: 314-322.
18. Pere A (2012) Déclin des populations de langouste rouge et baisse de la ressource halieutique en Corse: causes et perspectives. Université de Corse.

19. Marengo M, Patrissi M, Leduc M, Lejeune P, Gobert S (2018) La pêche artisanale de la langouste rouge autour du Cap Corse: évolution des captures, production, distribution spatiale, variation temporelle et démographique. PNMCCA/Rapport d'expertise. PNMCCA/Rapport d'expertise.

Your next submission with Juniper Publishers will reach you the below assets

- Quality Editorial service

- Swift Peer Review

- Reprints availability

- E-prints Service

- Manuscript Podcast for convenient understanding

- Global attainment for your research

- Manuscript accessibility in different formats

( Pdf, E-pub, Full Text, Audio)

- Unceasing customer service

Track the below URL for one-step submission https://juniperpublishers.com/online-submission.php 